\title{
PELAYANAN KESEHATAN DI RUMAH SAKIT UMUM DAERAH (RSUD) WONOSARI KABUPATEN GUNUNGKIDUL
}

\author{
Zulkifli Bima Zalwi ${ }^{1}$ dan Utami Dewi ${ }^{2}$
}

\begin{abstract}
This research aimed to determine the provision of health services in general hospital region of Wonosari, obstacles encountered in the provision of services and efforts made in overcoming these obstacles. The design of this research was descriptive method with a qualitative approach. The results showed that the provision of health services in general hospital region Wonosari had not fully fulfilled the overall principles of public service according to the decision of MENPAN No 63 of 2003, namely transparency, accountability, conditionality, participation, equal rights and balance rights and obligations. In the fulfillment of the Conditional Principles of RSUD Wonosari faces problem, such as infrastructure facilities in hospitals Wonosari inadequate, in particular intensive care unit. In the other hand,the obstacles of health service in RSUD Wonosari were lack of information on health and lack of capacity in human resources particulary the specialists. However by improving health service through the addition of human resources, RSUD Wonosari earned constructing new facilities to improving service performance.
\end{abstract}

Keywords: Health Service, General Hospital dan Regional

\begin{abstract}
ABSTRAK
Penelitian ini bertujuan untuk mengetahui penyediaan pelayanan kesehatan di RSUD Wonosari, kendala yang dihadapi dalam penyediaan pelayanannya dan upaya yang dilakukan dalam mengatasi kendala tersebut. Desain penelitian ini dengan metode deskriptif dengan pendekatan kualitatif. Hasil penelitian menunjukkan bahwa penyediaan pelayanan kesehatan di RSUD Wonosari belum sepenuhnya memenuhi keseluruhan dari asas pelayanan publik menurut Keputusan MENPAN No 63 tahun 2003 yaitu transparansi, akuntabilitas, kondisional, partisipan, kesamaan hak dan keseimbangan hak dan kewajiban. Dalam pemenuhan asas kondisional RSUD Wonosari menghadapi masalah antara lain sarana prasarana di RSUD Wonosari yang kurang memadai, khususnya pada unit perawatan intensif. Selain itu kendala yang dihadapi dalam pelaksanaan pelayanan kesehatan di RSUD Wonosari ialah kurangnya informasi tentang kesehatan dan sumber daya manusia khususnya dokter spesialis yang belum mencukupi. RSUD Wonosari melakukan perbaikan pelayanan kesehatan melalui penambahan SDM, pembangunan sarana baru dan peningkatan kualitas kinerja pelayanan.
\end{abstract}

Kata Kunci: Pelayanan Kesehatan, Rumah Sakit Umum, dan Daerah.

1,2 Jurusan Ilmu Administrasi Negara, Fakultas Ilmu Sosial, Universitas Negeri Yogyakarta 


\section{PENDAHULUAN}

\begin{abstract}
Pelayanan kesehatan merupakan suatu kebutuhan mendasar bagi setiap warga negara, dimana setiap warga negara berhak mendapatkan pelayanan kesehatan yang layak dan baik dari pemerintah. Dalam hal ini pelayanan kesehatan yang diberikan oleh pemerintah dilaksanakan melalui berbagai penyelenggaraan pelayanan kesehatan, dimulai dari adanya penyelenggaraan pelayanan kesehatan yang terdekat dengan masyarakat, yaitu penyelengaraan pelayanan kesehatan melalui puskesmas dan RSUD. Pelayanan kesehatan diatas terkait dengan pelayanan publik sebab pelayanan kesehatan publik menyangkut kepentingan orang banyak, masyarakat sering mengakses pelayanan tersebut sehingga dinilai sangatlah krusial.
\end{abstract}

Rumah Sakit Umum Daerah
(RSUD) Wonosari merupakan salah
satu rumah sakit bertipe C yang
berada di Kabupaten Gunungkidul
dimana merupakan rumah sakit umum
daerah yang keberadaan nya sangat
penting bagi masyarakat, dimana
RSUD Wonosari merupakan rumah sakit
terbesar yang terus berupaya melakukan
peningkatan baik mutu pelayanan maupun
fasilitas rumah sakit. Semakin hari RSUD
Wonosari menunjukkan ekistensinya

dalam memberikan pelayanan kesehatan kepada masyarakat di Kabupaten Gunungkidul dan sekitarnya.

Namun demikian, dalam praktiknya rumah sakit umum daerah yang memiliki penilaian yang tidak baik di masyarakat jika dibanding rumah sakit swasta karena dinilai masih memiliki kekurangan dalam kualitas pelayanan kesehatannya. Pelayanan kesehatan yang dimiliki oleh rumah sakit swasta lebih berorientasi pada kepentingan pelanggan dalam hal ini pasien rumah sakit, sehingga rumah sakit swasta cenderung memberikan pelayanan sebaik mungkin terhadap pasien, karena keberlangsungan rumah sakit swasta sangat tergantung pada keuntungan yang diterima dari para pelanggan (pasien). Hal ini berbeda dengan rumah sakit pemerintah, dimana sistem pelayanan yang dikembangkan dalam memberikan pelayanan kurang berorientasi pada kepentingan pengguna jasa.

Adapun permasalahan yang dihadapi oleh RSUD Wonosari adalah tenaga medis yang kurang dan sarana prasarana kesehatan yang tidak memadai sehingga masyarakat sepenuhnya belum bisa mendapatkan pelayanan secara maksimal. Disamping itu pelayanan yang 
ramah dan profesional sesuai dengan standar pelayanan publik masih belum dilaksanakan dengan benar oleh petugas medis, permasalahan keramahan, kesopanan dan kesabaran petugas menjadi keluhan bagi masyarakat penerima pelayanan di RSUD Wonosari. Tenaga medis di RSUD Wonosari terutama dokter, memang masih belum mencukupi. Permasalahan lain dimana sesuai dengan syarat ideal untuk paramedis, seharusnya satu tempat tidur, satu paramedis namun masih belum dimiliki. Sementara dokter spesialis bidang penyakit dalam, obgyn, anak, saraf, dan bedah harus memiliki minimal tiga orang dokter spesialis, namun di RSUD Wonosari baru dokter anak yang jumlahnya tiga, dokter bedah baru satu, dan yang lain nya hanya dua. RSUD Wonosari juga belum memiliki dokter spesialis urologi, gigi, hingga kulit dan kelamin.

Ratminto (2010:5) mendefinisikan pelayanan publik sebagai segala bentuk jasa pelayanan, baik dalam bentuk barang publik maupun jasa publik yang pada prinsipnya menjadi tanggung jawab dan dilaksanakan oleh instansi pemerintah di pusat, di daerah dan di lingkungan badan usaha milik negara (BUMN) atau badan usaha mulik daerah (BUMD), dalam rangka upaya pemenuhan kebutuhan masyarakat maupun dalam rangka pelaksanaan ketentuan peraturan perundang- undangan.

Oleh karena itu penyelenggaraan pelayanan publik di RSUD Wonosari harus memiliki standar pelayanan dan dipublikasikan sebagai jaminan adanya kepastian bagi penerima pelayanan. Standar pelayanan merupakan ukuran yang dibakukan dalam penyelenggaraan pelayanan publik yang wajib ditaati oleh pemberi dan atau penerima pelayanan. Menurut Keputusan MENPAN Nomor 63 tahun 2003, menyatakan bahwa standar pelayanan publik sekurang kurangnya meliputi prosedur pelayanan, waktu penyelesaian, biaya pelayanan, produk pelayanan, sarana dan prasarana, kompetensi petugas pemberi pelayanan. Sehingga jika dibanding dengan standar pelayanan tersebut, RSUD Wonosari masih belum memenuhi semua kriteria tersebut. Menurut Fitzsimmons dalam Sinambela (2008: 7-8) terdapat lima indikator pelayanan publik yaitu tangibles (bukti nyata), reliability (keandalan), responsiveness (daya tanggap), assurance (kepastian/jaminan) dan emphaty (empati).

Penelitian ini bertujuan untuk mengetahui kualitas pelayanan kesehatan 
di RSUD Wonosari sudah sesuai dengan asas pelayanan publik, peneliti menggunakan indikator pelayanan publik menurut Keputusan MENPAN Nomor 63 Tahun

$$
2003 \text { yaitu transparansi, }
$$
akuntabilitas, kondisional, partisipan, kesamaan hak, keseimbangan hak dan kewajiban, dimana peraturan tersebut menjadi pedoman bagi aparatur negara dalam menyelenggarakan pelayanan publik apakah sudah sesuai atau belum, lalu peneliti ingin mengetahui apa kendala yang dihadapi dalam proses pelayanannya sekaligus bagaimana upaya yang dilakukan dalam mengatasi kendala tesebut.

\section{METODE}

Penelitian ini merupakan penelitian deskriptif dengan menggunakan pendekatan kualitatif, yang bertujuan untuk mengali dan menjabarkan kondisi konkrit dari obyek penelitian dan selanjutnya dihasilkan diskripsi tentang obyek penelitian sehingga dapat membantu peneliti dalam mengetahui kualitas pelayanan kesehatan di RSUD Wonosari. Subjek pada penelitian ini adalah Kepala Bidang Pelayanan Medis dan Keperawatan RSUD Wonosari, Kepala Sub Bagian Data dan Rekam Medis RSUD Wonosari, Kepala Sub
Bagian Umum RSUD Wonosari dan Masyarakat pengguna pelayanan RSUD Wonosari.

Adapun sumber data yang digunakan dalam penelitian ini meliputi sumber data primer dan sumber data sekunder. Data Primer merupakan data yang diperoleh langsung dari lapangan. Sedangkan sumber sekunder yakni laporan dan profil RSUD Wonosari tahun 2016 serta peraturan yang terkait dengan penelitian ini sebagai bahan tambahan penguat data. Sumber data diperoleh dari berbagai buku, jurnal, tesis, skripsi, sumber internet yang terkait dengan penelitian ini. Instrumen dalam penelitian ini adalah peneliti itu sendiri dibantu dengan pedoman wawancara, pedoman observasi serta dokumentasi yang di diperoleh dari data sekunder.

Penelitian ini menggunakan teknik triangulasi sumber untuk memeriksa keabsahan data. Peneliti membandingkan dan mengecek balik derajat kepercayaan suatu informan yang diperoleh melalui waktu dan alat yang berbeda. Sedangkan teknik analisis data yang digunakan adalah teknik analisis model interaktif Milles dan Huberman (Sugiyono, 2011:246). Teknik ini meliputi pengumpulan data, reduksi data, penyajian 
data, dan penarikan kesimpulan atau verifikasi.

\section{HASIL DAN PEMBAHASAN}

Reformasi dibidang kesehatan dilaksanakan untuk meningkatkan pelayanan kesehatan dan menjadikannya lebih efisien, efektif serta dapat dijangkau oleh seluruh lapisan masyarakat. Seperti yang tertuang dalam Keputusan Menteri Kesehatan Republik Indonesia No. 951/Menkes/SK/VI/2000 yaitu bahwa tujuan pembangunan kesehatan adalah untuk meningkatkan kesadaran, kemauan dan kemampuan hidup sehat bagi setiap orang agar terwujud derajat kesehatan masyarakat yang optimal. Dengan semakin meningkatnya tingkat pendidikan dan keadaan sosial dalam masyarakat, maka meningkat pula kesadaran akan arti hidup sehat dan keadaaan tersebut menyebabkan tuntutan masyarakat akan pelayanan kesehatan yang bermutu, nyaman dan berorientasi pada kepuasan konsumen semakin mendesak dimana diperlukan kinerja pelayanan yang tinggi.

RSUD Wonosari merupakan salah satu badan layanan umum daerah yang melayani masyarakat khususnya di Kabupaten Gunungkidul dalam bidang kesehatan perlu melaksanakan asas pelayanan publik yang prima demi mewujudkan kualitas kesehatan masyarakat yang baik dan tercukupi kebutuhannya. Dengan indikator keputusan MENPAN No 63 tahun 2003 dijelaskan bahwa asas pelayanan publik harus memenuhi asas sebagai berikut yaitu transparansi, akuntabilitas, kondisional, partisipan, kesamaan hak dan keseimbangan hak dan kewajiban. Dengan berjalannya ke enam asas-asas tersebut maka pelayanan publik di RSUD Wonosari sudah melaksanakan pelayanan kesehatan mereka dengan prima.

\section{Kualitas Pelayanan Kesehatan di RSUD Wonosari}

1. Transparansi

Asas mengenai transparansi merupakan bentuk keterbukaan pelayanan publik yang bersifat mudah dan dapat diakses oleh semua pihak yang membutuhkan, dimana ketersediaannya memadai untuk publik serta mudah dimengerti oleh semua orang. Sebagai salah satu lembaga pemerintahan yang mempunyai tugas dalam pelayanan publik, RSUD Wonosari juga harus menerapkan asas transparansi tersebut, dimana pelayanan publik dalam bidang kesehatan dapat bersifat terbuka, dapat diakses dan mudah dimengerti. Dalam hal 
tersebut bentuk transpaansi pelayanan kesehatan yang dilakukan oleh RSUD Wonosari mencakup mengenai sistem informasi pelayanan kesehatannya, dimana sistem tersebut dapat membantu dalam mencapai proses pelayanan yang bersifat transparan.

Penggunaan sistem komputerisasi dalam pelaksanaan kegiatan di RSUD Wonosari sudah dilakukan, agar terciptanya efektivtas dan efisiensi serta keterbukaan kepada masyarakat. Penggunaan layanan call center, pemasangan videotron juga mampu menyampaikan informasi kepada masyarakat mengenai pelayanan kesehatan, kemudian keluhan ketidakpuasan di tambah lagi penyampaian informasi dan berita melalui website internet juga membantu keterbukaan kepada masyarakat.

\section{Akuntabilitas}

Akuntabilitas merupakan asas pelayanan publik yang dimana organisasi publik atau kelompok dapat mempertanggungjawabkan proses pelayanan publiknya dimana sesuai dengan peraturan perundang-undangan. Dalam hal ini RSUD Wonosari sebagai lembaga pemeintahan juga harus ikut dan mematuhi peraturan yang berlaku serta mempertanggung jawabkannya.
RSUD Wonosari menerapkan hal-hal yang terkait pelayanan kesehatan mereka dengan menganut UU No. 44 tahun 2009.

Dikutip dalam Undang-Undang No. 44 Tahun 2009 tentang Rumah Sakit, disebutkan Rumah Sakit adalah institusi pelayanan kesehatan yang menyelenggarakan pelayanan kesehatan perorangan secara paripurna yang menyediakan pelayanan rawat inap, rawat jalan, dan gawat darurat. Pelayanan Kesehatan Paripurna adalah pelayanan kesehatan yang meliputi promotif, preventif, kuratif, dan rehabilitatif. Dalam UU tersebut, ada persyaratan tentang rumah sakit daerah yaitu Rumah Sakit yang didirikan oleh Pemerintah dan Pemerintah Daerah harus berbentuk Unit Pelaksana Teknis dari Instansi yang bertugas di bidang kesehatan, Instansi tertentu, atau Lembaga Teknis Daerah dengan pengelolaan Badan Layanan Umum (BLU) atau Badan Layanan Umum Daerah (BLUD) sesuai dengan ketentuan peraturan perundang- undangan. Saat ini banyak RSUD bergeser menjadi pengelolaan secara Badan Layanan Umum. Hal dimana mewajibkan RSUD tidak hanya harus dapat memenuhi SPM saja, tetapi harus bisa meningkatkan pelayanan, meningkatkan efisiensi dan 
efektivitas, serta bisa dijangkau oleh semua lapisan masyarakat.

Pemberlakuan BLUD bertahap di RSUD Wonosari sejak tahun 2010, khususnya untuk kegiatan pelayanan kesehatan, telah menunjukan hasil yang cukup menggembirakan dari segi pengelolaan pelayanan. Namun demikian seiring dengan perjalanan waktu, ada beberapa kendala mengiringi pelaksanaan kegiatan pelayanan kesehatan pada beberapa unit dan isntalasi yang tergambar dari pencapaian kinerja layanan. RSUD Wonosari membuat ringkasan kegiatan selama setauhun, kegiatan pelayanan ini yang merupakan bagian dari laporan kinerja rumah sakit yang memuat hasil kegiatan segala aspek pelayanan kesehatan baik dalam bentuk narasi, penyajian data, dan analisisnya, sebagai wujud dari pelaksanaan tugas yang diberikan yang kemudian disampaikan kepada Pemerintah Daerah Kabupaten Gunungkidul sebagai bentuk pertanggungjawaban pihak rumah sakit.

\section{Kondisional}

Asas kondisional ini mengenai kesesuaian kondisi, keadaan dan kemampuan dari pemberi dan penerima pelayanan publik dengan tetap memegang pada prinsip efisiensi dan efektivitas. Dalam hal tersebut RSUD melaksanakan pelayanan kesehatan mereka dengan menyesuaikan kondisi dan kemampuan mereka dalam melakukan pelayanan publik, sehingga terciptanya suatu pelayanan yang efektif dan efisien sesuai dengan asas pelayanan publik yang baik.

Proses pelayanan yang meliputi kemudahan askes, kecepatan pelayanan sudah dinilai baik oleh masyarakat pengguna jasa layanan RSUD. Pegawai RSUD dianggap sudah memberikan kemudahan bagi masyarakat untuk menggunakan askes saat pendaftaran pasien ketika mendapatkan ruang rawat inap serta pegawai administrasi pendaftaran memberikan kecepatan pelayanan.

Dikutip dari profil RSUD Wonosari tahun 2016 bahwa pada sarana ruang pada pasien RSUD Wonosari memiliki sebanyak 186 ruang, dimana masih belum adanya beberapa ruang seperti ruang VVIP, PICU (ruang intensif untuk anak usia 29 hari samapi dengan 18 tahun), NICU (ruang intensif untuk bayi baru lahir) dan $\mathrm{HCU}$ (high care unit). Dilihat dari pernyataan sebelumnya dapat diketahui bahwa sarana penunjang pelayanan kesehatan di RSUD Wonosari masih lah kurang, sehingga 
pasien khusus sering dirujuk ke rumah sakit yang lebih memiliki fasilitas memadai pendukung di Yogyakarta. Namun menurut dari hasil pengamatan, pihak RSUD Wonosari masih dalam proses untuk terus membangun fasilitas kesehatan yang kurang, yang dimana pada tahun 2017 ini RSUD sudah membangun Instalasi Gawat Darurat (IGD) yang baru dan Instalasi bedah Urologi sehingga hal ini dapat membantu meningkatkan kualitas pelayanan yang ada di RSUD Wonosari.

\section{Partisipasi}

\section{Partisipan/Partisipasi merupakan} asas yang mendorong masyaratkat berperan serta dalam penyelenggaraan pelayanan publik namun dengan memperhatikan aspirasi, kebutuhan dan harapan publik sehingga proses pelayanan publik tidak hanya satu arah saja, hal tersebut dapat membantu pelayan publik dalam memperbaiki bagaimana proses penyediaan pelayanan publik mereka. Dalam hal partisipan, RSUD Wonosari juga menerapkan program dalam mengikutsertakan masyarakat secara aktif dalam proses penerimaan pelayanan kesehatan, dimana hal tersebut dapat membantu mempermudah proses pelayanan dan juga memperbaiki kekurangan-kekurangan yang ada.
Pemahaman sudah dilakukan dari pihak RSUD ke pasien melalui komunikasi lisan. Namun hal tersebut dirasa belum efektif karena masih ada keluhan yang masuk, dimana informasi mengenai RSUD belum jelas dan dipahami oleh masyarakat. Untuk itu, pihak RSUD Wonosari membuat form edukasi yang diberikan sebagai upaya memberikan solusi dari permasalahan tersebut. Form edukasi ini berisi tentang materi pendidikan kesehatan yang akan disampaikan oleh pihak RSUD Wonosari (Dokter, perawat atau staff) kemudian akan ditinjau serta di cek oleh pihak RSUD secara berkala sehingga pasien mengerti mengenai masalah kesehatan yang dialami.

Form tersebut bertujuan untuk memberi ilmu dan pengetahuan kepada pasien atau keluarga mengenai permasalahan kesehatan, sehingga pasien akan ikut serta aktif akan masalah kesehatan yang dihadapi. Selain itu form ini juga dapat berfungsi untuk memantau pasien yang sudah sembuh agar dapat $m$ engetahui hal-hal apa yang perlu dilakukan dalam menjaga kesehatan mereka.

\section{Kesamaan Hak}

Sesuai asas ini kesamaan hak merupakan tindakan pelayanan publik 
dimana tidak melakukan diskriminatif, tidak membedakan suku, ras, agama, golongan dan sebagainya dalam proses pelayanan publik kepada masyarakat. Sebagai rumah sakit daerah yang dimana masyarakat sangat membutuhkan pelayanan kesehatannya, RSUD Wonosari mempunyai hal yang berdampak vital manakala keadaan masyarakat yang berbeda- beda dan mempunyai hak yang sama untuk mendapatkan pelayanan kesehatan.

Persamaan hak dengan tanpa membeda- bedakan dalam penyediaan pelayanan kesehatan di RSUD Wonosari menjadi suatu hal yang dikedepankan, di samping kualitas yang baik pihak rumah sakit juga menjaga kepercayaan masyarakat dalam melakukan pelayanan kesehatan. Banyaknya sentimen negatif terhadap pasien dengan bantuan kesehatan seperti BPJS, Jamkesta, ataupun Kartu Indonesia Sehat yang datang ke rumah sakit akan di layani berbeda dengan pasien umum lain sehingga dapat menurunkan kepercayaan dan menyalahi komitmen RSUD Wonosari yang melayani pasien secara adil dan sama.

\section{Keseimbangan Hak dan Kewajiban}

Keseimbangan hak dan kewajiban dalam asas penyelanggaraan pelayanan publik ini adalah dimana pemberi dan penerima pelayanan publik dapat saling memenuhi hak dan kewajiban masingmasing yang sudah disepakati dan terdapat pada peraturan tertentu. RSUD Wonosari juga menerapkan asas ini sesuai pada undang-undang mengenai rumah sakit yang berlaku dimana saling menghormati dan menghargai antara masyarakat dan pihak rumah sakit agar terciptanya keseimbangan sehingga tidak akan terjadi overlap kepentingan antara satu sama lain.

Sebagai rumah sakit daerah milik pemerintah, RSUD Wonosari berpegang pada peraturan perundang-undangan yang berlaku. Disini RSUD Wonosari menjalankan penyediaan pelayanan kesehatan sesuai dengan UU no 44 tahun 2009 tentang rumah sakit, dimana tetap memperhatikan hak dan kewajiban dari masing-masing pihak yaitu antara pihak rumah sakit maupun pasien. Sesuai dengan undang-undang tersebut pelayanan kesehatan di RSUD Wonosari dilaksanakan. Untuk keseimbangan antara kewajiban dan hak rumah sakit dalam hal ini sudah dilaksanakan, rumah sakit mempunyai kewajiban untuk memberikan pelayanan yang baik kepada pasien sedangkan rumah sakit berhak untuk mendapatkan imbalan biaya jasa dari pasien sesuai dengan pelayanan yang 
diterima, atau dapat disebut take and give dengan adil dan setara.

Sedangkan jika dilihat dari keseimbangan antara hak dan kewajiban dimana pasien mempunyai kewajiban dalam menaati seluruh peraturan dan tata tertib selama berada di RSUD Wonosari, begitu juga dalam mendapatkan hak dalam mendapatkan pelayanan yang sesuai begitu juga sebaliknya pada pihak rumah sakit menurut UU No 44 tahun 2009 tentang penyelenggaraan rumah sakit.

Kendala Pelayanan Kesehatan di RSUD Wonosari

Adapun kendala pelayanan kesehatan di RSUD Wonosari adalah banyaknya pasien dan masyarakat yang belum mengetahui mengenai informasi kesehatan di rumah sakit tersebut sehingga banyaknya keluhan-keluhan yang masuk, dimulai dari lamanya pelayanan hingga informasi mengenai pelayanan yang tidak jelas. Dalam penerapan Sistem Informasi Pelayanan Kesehatan di RSUD Wonosari awalnya berjalan kurang lancar, banyak hambatan yang dihadapi di dalam penggunaan sistem informasi pelayanan tersebut. Masalah sumber daya manusia di dalam penguasaan Teknologi Informasi (TI) menjadi kendala utama dalam penggunaan sistem informasi ini, hal ini mengakibatkan kurang sesuainya hasil yang diharapkan pada awal penerapan sistem informasi ini.

Kendala kedua, RSUD Wonosari masih belum memiliki SDM yang memadai untuk melakukan pelayanan kesahatan untuk seluruh pasien. Jumlah tenaga medis yang dimiliki RSUD hanya berjumlah 26 pada bagian dokter, hal tersebut dirasa kurang untuk melayani pasien yang ada. Pihak rumah sakit masih kekurangan dokter pada bidang spesialis dan sub spesialis, khususnya dalam bedah urologi yang masih kurang. Penambahan tenaga medis masih dilakukan pihak RSUD, namun belum tersedianya dokter di Kabupaten Gunungkidul menjadi kendala. Kekurangan ini dikarenakan belum adanya dokter spesialis yang berdomisili di wilayah Kabupaten Gunungkidul sehingga pihak RSUD harus mencari dokter yang ada di Kabupaten lain, oleh karena jarak dan kendala geografis tersebut banyak dokter yang belum berkenan untuk menjadi dokter di RSUD Wonosari. Dokter-dokter yang ada di RSUD Wonosari, dimana sebagian besar juga berasal dari luar Kabupaten Gunungkidul sehingga masih sedikitnya dokter yang berdomisili asli 
asal Gunungkidul menjadi kendala dalam penambahan SDM yang diperlukan.

Ketiga, sarana dan prasarana yang ada di RSUD Wonosari belum sesuai dengan jenis maupun jumlahnya. Misalnya seperti ruang rawat inap, fasilitas tunggu bagi keluarga pasien maupun sarana dan prasarana bagi pegawai RSUD Wonosari. Lingkungan pelayanan kurang memberikan rasa nyaman bagi pasien dan keluarga pasien terutama aspek kebersihan, ketenangan, keamanan, kenyamanan bagi pasien dan keluarga pasien. Kurang nyamannya pasien dapa dilihat dari belum adanya lahan parkir yang luas, ruang tunggu pasien mendaftar yang belum memadai hingga tidak adanya sarana atau fasilitas pendukung untuk penunggu pasien rawat inap seperti kantin. Beberapa poli kesehatan masih belum memadai kebutuhan seluruh pasien karena terkendala masalah kurangnya ruang dan sumber daya manusia.

Hal ini sangat mempengaruhi kualitas pelayanan kesehatan yang ada, jika tidak didukung oleh sarana dan prasarana yang memadai akan menimbulkan sentimen negatif terhadap pihak RSUD Wonosari. Dengan adanya penambahan fasilitas baru diatas akan meningkatkan kulaitas pelayanan sesuai dengan standar pelayanan publik.

\section{Upaya mengatasi Kendala \\ Pelayanan Kesehatan di RSUD Wonosari}

Penambahan petugas medis pada RSUD Wonosari telah dilakukan secara berkala, yang terbaru dalam menghadapi masalah kekurangan sumber daya kesehatan di RSUD Wonosari, pihak rumah sakit membuka seleksi dalam perekrutan pegawai non PNS untuk menambah jumlah tenaga kerja yang ada demi menciptakan pelayanan kesehatan yang baik sesuai dengan prinsip efisiensi dan evektifitas. Pada tahun akhir 2016 RSUD Wonosari membuka penerimaan tenaga kesehatan sebanyak lebih kurang 55 orang, yaitu terdiri dari 3 orang dokter umum, 5 orang tenaga bidan, 32 orang perawat umum, 4 orang apoteker, $\quad 8$ orang asisten apoteker, 2 orang Nutrisionis, 2 orang tenaga pemasak serta masing-masing 1 orang tenaga informatika, 1 orang tenaga listrik dan 1 orang sanitarian. Hal ini merupakan upaya positif dalam mengatasi kendala sumber daya yang ada, walaupun jumlah rekrutmen masih belum memenuhi target dari rencana pihak RSUD Wonosari yaitu jumlah keseluruhan pegawai hanya 436 
orang (minus rekrutmen baru) sedangkan target yang ditentukan berjumlah 559 pegawai. Untuk hal itu pihak RSUD juga membuat sistem kontrak pegawai atau petugas dalam memenuhi kebutuhan pelayanan kesehatan yang memadai.

Upaya ini merupakan upaya yang paling dapat terlihat secara kasat mata jika dibanding dengan kedua upaya yang sebelumnya, dimana pembangunan sarana dan prasarana ini membutuhkan biaya dan perencanaan yang matang untuk mewujudkannya. Dalam hal ini RSUD Wonosari sudah melaksanakan program pembangunan, dimana pembuatan gedung baru yaitu gedung ICU, gedung klas II dan gedung Radiologi, pendanaan pembangunan melalui dana BLUD dan bantuan pemerintah Kabupaten Gunungkidul sudah selesai pembangunannya walaupun belum dipakai. Sedangkan penambahan ruang rawat inap juga masih dalam proses sehingga masih menunggu peneyelesaian pembangunannya, dan juga beberapa fasilitas penunjang lain seperti jalur masuk akses ke layanan IGD diperbaiki mendekat kepada jalan raya sehingga lebih memudahkan akses pasien masuk. Menurut pihak RSUD Wonosari bahwa pembangunan masih terus akan dilakukan namun hal tersebut masih terhalang luas wilayah rumah sakit dengan demikian RSUD Wonosari berencana menambah sarana dan prasarana dengan membangun secara bertingkat sehingga mempermudah dalam mendapatkan lahan.

\section{SIMPULAN}

Berdasarkan penelitian dan pembahasan, maka dapat ditarik kesimpulan bahwa kualitas pelayanan kesehatan pada RSUD Wonosari berdasarkan asas pelayanan publik menurut Keputusan MENPAN No 63 tahun 2003 yaitu transparansi, akuntabilitas, kondisional, partisipan/partisipasi, kesamaan hak dan keseimbangan hak dan kewajiban, pelayanan kesehatan di RSUD Wonosari sudah memenuhi keseluruhan asas tersebut secara optimal kecuali pada asas kondisional.

Untuk memenuhi asas- asas menurut Keputusan MENPAN no 63 tahun 2003 tersebut secara optimal, RSUD Wonosari telah melakukan pelayanan yang terbuka dan menjangkau seluruh masyarakat tanpa membeda- bedakan latar belakang status, serta mengikutsertakan masyarakat dengan mengadakan penyuluhan dan diskusi mengenai 
kesehatan. Pembuatan laporan tahunan tentang kinerja pelayanan merupakan bentuk pertanggungjawaban RSUD Wonosari terhadap pemerintah, kemudian pelaksanaan UU no 44 tahun 2009 tentang rumah sakit sebagai acuan RSUD Wonosari dalam memenuhi asas-asas tersebut.

Sedangkan sesuai asas kondisional, pelayanan kesehatan di RSUD Wonosari sangat kurang optimal, kendala masalah sumber daya, fasilitas kesehatan yang belum memadai membuat rumah sakit belum mampu memenuhi kebutuhan, disamping itu pelayanan kesehatan kepada pasien pengguna BPJS atau program sejenis lainnya dilaksanakan dengan baik, namun masih banyak masalah mengenai pelayanannya yang dirasa belum memuaskan.

Adapun kendala pokok dalam pelayanan kesehatan di RSUD Wonosari Permasalahan pokok dalam pelayanan kesehatan di RSUD Wonosari ialah kurang memadainya sumber daya manusia terutama dokter spesialis, kemudian sarana prasarana yang kurang dalam memenuhi kebutuhan pasien khusus, masih adanya fasilitas yang belum ada di RSUD Wonosari.

Oleh karena itu, upaya mengatasi kendala- kendala tersebut pihak RSUD Wonosari sudah melakukan rekrutmen pegawai dalam upaya menambah kinerja pelayanan yang profesional dan cepat, serta pembangunan sarana dan prasarana baru penunjang pelayanan kesehatan.

\section{DAFTAR PUSTAKA}

Lexy J. Moleong. 2005. Metodelogi Penelitianb Kualitatif. Bandung :PT Remaja rosdakarya

Moenir, AS. 2010. Manajemen Pelayanan Umum di Indonesia. Jakarta: Bumi Aksara.

Ratminto dan Atik Septi Winarsih. 2010. Manajemen Pelayanan: Penembangan Model Konseptual, Penerapan Citizen's Charter dan Standar Pelayanan Minimal. Yogyakarta: Pustaka Pelajar

Sinambela, L.P. 2008. Reformasi Pelayanan Publik: Teori, Kebijakan dan Implementasi. Jakarta: Bumi Aksara.

Sugiyono, 2011. Metodelogi Penelitian Administrasi RD. Bandung: Alfabeta

Sri Kusumadewi, dkk. 2009. Informatika Kesehatan. Yogyakarta : Graha Ilmu

$\begin{array}{crr}\text { Keputusan } & \text { Menteri } & \text { Kesehatan } \\ \text { Republik } & \text { Indonesia } & \text { No. } \\ \text { 951/Menkes/SK/VI/2000 } & \end{array}$


Menteri Pendayagunaan Aparatur Negara RI. 2004. "Keputusan Menteri Pendayagunaan Aparatur Negara

No.63/KEP/M.PAN/7/2003/

Tentang Pedoman Pelayanan Publik " Undang-Undang No 44 Tahun 2009 Tentang Rumah Sakit

Profil RSUD Wonosari tahun 2016 http://koransindo.com/page/news/2016-05 18/6/120 diakses tgl 22 April 2017 